University of Nebraska - Lincoln

DigitalCommons@University of Nebraska - Lincoln

USDA Forest Service / UNL Faculty Publications U.S. Department of Agriculture: Forest Service --

National Agroforestry Center

2005

\title{
Seasonal leaf dynamics across a tree density gradient in a Brazilian savanna
}

\author{
William A. Hoffman \\ North Carolina State University \\ Edson Rangel da Silva Jr. \\ Universidade de Brasília \\ Gustavo C. Machado \\ Universidade de Brasília \\ Sandra J. Bucci \\ University of Miami \\ Fabian G. Scholz \\ Universidad de Buenos Aires \\ See next page for additional authors
}

Follow this and additional works at: https://digitalcommons.unl.edu/usdafsfacpub

Part of the Forest Sciences Commons

Hoffman, William A.; da Silva Jr., Edson Rangel; Machado, Gustavo C.; Bucci, Sandra J.; Scholz, Fabian G.; Goldstein, Guillermo; and Meinzer, Frederick C., "Seasonal leaf dynamics across a tree density gradient in a Brazilian savanna" (2005). USDA Forest Service / UNL Faculty Publications. 61.

https://digitalcommons.unl.edu/usdafsfacpub/61

This Article is brought to you for free and open access by the U.S. Department of Agriculture: Forest Service -National Agroforestry Center at DigitalCommons@University of Nebraska - Lincoln. It has been accepted for inclusion in USDA Forest Service / UNL Faculty Publications by an authorized administrator of DigitalCommons@University of Nebraska - Lincoln. 


\section{Authors}

William A. Hoffman, Edson Rangel da Silva Jr., Gustavo C. Machado, Sandra J. Bucci, Fabian G. Scholz, Guillermo Goldstein, and Frederick C. Meinzer 


\section{William A. Hoffmann · Edson Rangel da Silva Jr Gustavo C. Machado · Sandra J. Bucci \\ Fabian G. Scholz · Guillermo Goldstein \\ Frederick C. Meinzer \\ Seasonal leaf dynamics across a tree density gradient in a Brazilian savanna}

Received: 11 November 2004/ Accepted: 7 April 2005/Published online: 18 June 2005

(C) Springer-Verlag 2005 This article is a U.S. government work, and is not subject to copyright in the United States.

\begin{abstract}
Interactions between trees and grasses that influence leaf area index (LAI) have important consequences for savanna ecosystem processes through their controls on water, carbon, and energy fluxes as well as fire regimes. We measured LAI, of the groundlayer (herbaceous and woody plants $<1-\mathrm{m}$ tall) and shrub and tree layer (woody plants $>1-\mathrm{m}$ tall), in the Brazilian cerrado over a range of tree densities from open shrub savanna to closed woodland through the annual cycle. During the dry season, soil water potential was strongly and positively correlated with grass LAI, and less strongly with tree and shrub LAI. By the end of the dry
\end{abstract}

Communicated by Jim Ehleringer

W. A. Hoffmann $(\bowtie)$

Department of Botany, North Carolina State University, Campus Box 7612, Raleigh, NC 28695-7612, USA

E-mail: william_hoffmann@ncsu.edu

Tel.: + 1-919-5137668

Fax: + 1-919-5153436

E. R. da Silva Jr · G. C. Machado

Departamento de Engenharia Florestal,

Universidade de Brasília,

Caixa Postal 04357, Brasília, DF 70919-970, Brazil

Present address: E. R. da Silva Jr

Instituto Brasileiro do Meio Ambiente e dos Recursos Naturais

Renováveis (IBAMA) SCEN trecho $02-\mathrm{LPF}$,

Ed.sede Brasília, DF, Brazil

S. J. Bucci · G. Goldstein

Department of Biology, University of Miami,

Coral Gables, Florida 33124, USA

F. G. Scholz · G. Goldstein

Laboratorio de Ecología Funcional,

Departamento de Ciencias Biológicas,

Facultad de Ciencias Exactas y Naturales,

Universidad de Buenos Aires, Ciudad Universitaria,

Nuñez, Buenos Aires, Argentina

F. C. Meinzer

USDA Forest Service, Forestry Sciences Laboratory, 3200 SW Jefferson Way, Corvallis, OR 97331, USA season, LAI of grasses, groundlayer dicots and trees declined to 28,60 , and $68 \%$ of mean wet-season values, respectively. We compared the data to remotely sensed vegetation indices, finding that field measurements were more strongly correlated to the enhanced vegetation index (EVI, $\left.r^{2}=0.71\right)$ than to the normalized difference vegetation index (NDVI, $r^{2}=0.49$ ). Although the latter has been more widely used in quantifying leaf dynamics of tropical savannas, EVI appears better suited for this purpose. Our ground-based measurements demonstrate that groundlayer LAI declines with increasing tree density across sites, with savanna grasses being excluded at a tree LAI of approximately 3.3. LAI averaged 4.2 in nearby gallery (riparian) forest, so savanna grasses were absent, thereby greatly reducing fire risk and permitting survival of fire-sensitive forest tree species. Although edaphic conditions may partly explain the larger tree LAI of forests, relative to savanna, biological differences between savanna and forest tree species play an important role. Overall, forest tree species had $48 \%$ greater LAI than congeneric savanna trees under similar growing conditions. Savanna and forest species play distinct roles in the structure and dynamics of savanna-forest boundaries, contributing to the differences in fire regimes, microclimate, and nutrient cycling between savanna and forest ecosystems.

Keywords Cerrado - Leaf area index - Phenology · Tropical forest $\cdot$ Water potential

\section{Introduction}

Leaves are the primary site for the exchange of water, carbon, and energy between terrestrial vegetation and the atmosphere. Therefore, leaf area index (LAI) is a primary determinant of ecosystem function and governs net primary productivity, water balance, and energy balance (Bonan 2002; Asner et al. 2003). Soils and 
climate exert strong controls on LAI, but understanding these controls is made difficult by spatial and temporal changes in species and life-form composition.

The role of species composition in modulating environmental controls on LAI should be particularly important in tropical savannas, characterized by a continuous grass layer interspersed with trees. Trees and grasses differ greatly in rooting depth, and consequently in leaf phenology, so the relative abundance of deeprooted trees versus shallow-rooted grasses will largely determine seasonality in LAI. Furthermore, the groundlayer comprises a diversity of growth forms in addition to graminoids, including herbaceous dicots, subshrubs and juvenile shrubs and trees. Despite their low stature, these groundlayer dicots can have deep roots (Rizzini and Heringer 1961; Moreira and Klink 2000), which might permit them to maintain leaf area during the dry season, though there appears to be little information about the phenology of this component.

Interactions between trees and grasses are likely to influence leaf dynamics in ways not expected based on simple mixing of species of different phenological patterns. Trees can have negative effects on grasses through competition for light, nutrients, and water (Belsky 1994; Le Roux et al. 1995; Ludwig et al. 2004), but can also have positive effects by increasing resource levels or ameliorating environmental stresses. During the dry season, hydraulic lift, i.e., passive transport of water from deep soil layers to shallow layers, can increase water availability for herbaceous plants (Scholz et al. 2002; Ludwig et al. 2003; Moreira et al. 2003). Shading reduces light availability for grasses, but ameliorates soil and air temperatures, thereby reducing grass water stress and soil water loss. Furthermore, soil beneath savanna trees is often enriched, due to greater deposition of organic matter (Kellman 1979; Weltzin and Coughenour 1990; Isichei and Muoghalu 1992; Mordelet et al. 1993; Hibbard et al. 2001). The relative strength of the various positive and negative effects of trees on grasses is quite variable (Mordelet and Menaut 1995), and is likely to depend on tree density (Scholes and Archer 1997) and season. In the dry season, when grasses are strongly limited by water availability, positive effects of shading and hydraulic lift should be more important, so seasonality in groundlayer LAI might be lower where tree density is greater.

Interactions between trees and grasses also play an important role in savanna-forest dynamics. Because of the presence of grasses, savanna vegetation is very flammable, whereas, evergreen forest is not typically flammable due to the dense canopy that excludes grasses and maintains a more humid understorey (Uhl and Kauffman 1990). Therefore, most savanna fires do not penetrate far into undisturbed evergreen forest (Kellman and Meave 1997; Biddulph and Kellman 1998). Edaphic conditions are often considered responsible for this difference in tree canopy cover between savanna and forests. Indeed, there is often an association between soil resources and savanna/forest boundaries, though in many cases the association is weak or altogether nonexistent (Furley 1992; Haridasan 1992; Schwartz et al. 1996; Bowman 2000; Fölster et al. 2001).

An alternative hypothesis is that savanna tree species, even when occurring in high density, are unable to develop sufficiently high LAI to exclude savanna grasses through shading. Shade intolerant species often have low LAI (Mourelle et al. 2001; Sterck et al. 2001; Reich et al. 2003), perhaps because shade tolerance is necessary for maintaining positive leaf carbon balance under the intense self-shading occurring with high LAI. Therefore, the maximum LAI attained by savanna species may be limited by their shade intolerance. Maximum LAI may be further limited by the tortuous architecture and irregular branching pattern typical of savanna trees, which should reduce their ability to efficiently display leaves in a way that maximizes light interception.

It is within this context that we examined the spatial and temporal variation in LAI in Cerrado savannas of Brazil. We quantified seasonal variation in leaf area index across a range of tree cover in cerrado savanna. We hypothesized that (1) grass LAI will be more strongly seasonal than tree LAI, (2) grass LAI is negatively correlated with tree LAI, but the seasonal variation in grass LAI is lower in sites with high tree density, and (3) forest tree species develop higher LAI than savanna tree species under similar growing conditions. To test these hypotheses, we quantify the annual cycle in LAI of the woody and herbaceous species across a range of trees densities. Additionally, we compare the LAI of savanna and forest species using phylogenetically independent contrasts based on congeneric species pairs.

\section{Study site}

Tree density in the Cerrado region is heterogeneous, with savanna vegetation ranging from open grassland (campo limpo), through a gradient of increasing tree density (campo sujo, campo cerrado, cerrado sensu stricto, and cerrado denso) to nearly closed-canopy woodland (cerradão). Across these savanna physiognomies, tree density is somewhat correlated with soil nutrient status (Goodland and Ferri 1979), though it is more strongly associated with topography, with denser formations occurring on deep, well-drained soils of the uplands and more open formations typically occurring on shallow or coarse soils. Evergreen gallery forest occurs along rivers, while evergreen, semideciduous, and deciduous forests occur locally on upland sites.

Data were collected at the Ecological Reserve of IBGE (Instituto Brasileiro de Geografia e Estatística) located near Brasília in the Federal District, Brazil at an elevation of approximately $1,100 \mathrm{~m}$. Mean annual rainfall at the meteorological station in IBGE was 1,426 $\mathrm{mm}$ for 1993-2002, with a distinct dry season from May to September and mean annual temperature of $22.5^{\circ} \mathrm{C}$. 
Five sites were chosen to represent a range of tree densities typical of the cerrado:

1. Campo sujo, an open shrub savanna with basal area of $4.3 \mathrm{~m}^{2} \mathrm{ha}^{-1}\left(15^{\circ} 56^{\prime} 02^{\prime \prime} \mathrm{S}, 47^{\circ} 52^{\prime} 26^{\prime \prime} \mathrm{W}\right)$.

2. Campo cerrado, open tree and shrub savanna with basal area of $4.4 \mathrm{~m}^{2} \mathrm{ha}^{-1}\left(15^{\circ} 57^{\prime} 39^{\prime \prime} \mathrm{S}, 47^{\circ} 53^{\prime} 05^{\prime \prime} \mathrm{W}\right)$.

3. Cerrado sensu stricto, 'typical' cerrado, i.e., tree savanna with basal area of $10.7 \mathrm{~m}^{2} \mathrm{ha}^{-1}\left(15^{\circ} 57^{\prime} 19^{\prime \prime} \mathrm{S}\right.$, $47^{\circ} 52^{\prime} 22^{\prime \prime} \mathrm{W}$ ).

4. Cerrado denso, dense tree savanna, with basal area of $18.2 \mathrm{~m}^{2} \mathrm{ha}^{-1}\left(15^{\circ} 57^{\prime} 15^{\prime \prime} \mathrm{S}, 47^{\circ} 52^{\prime} 44^{\prime \prime} \mathrm{W}\right)$.

5. Cerradão, a nearly closed-canopy woodland, with basal area of $26.6 \mathrm{~m}^{2} \mathrm{ha}^{-1}$.

In addition to these intensely studied sites, point measurements were made in three gallery forests, as described below. None of the study sites had burned within several years prior to the study.

\section{Methods}

\section{Groundlayer LAI}

We estimated groundlayer LAI with a LAI 2000 Plant Canopy Analyzer (LI-COR Inc., Lincoln, Nebraska, USA). The LAI-2000 estimates LAI by comparing light intensity at various angles for measurements performed above and below the canopy (LI-COR, 1992). To estimate groundlayer LAI, the above-canopy measurement was performed above the groundlayer but under tree cover, when present, as described by LI-COR (1992). A $180^{\circ}$ view cap was used to block the silhouette of the operator during measurements. All herbaceous plants, as well as woody plants $<1$-m tall were considered to belong to the groundlayer, while larger woody plants were pooled into a single category of trees and shrubs.

The LAI-2000 does not distinguish between leaves and stems, so it yields an estimate of vegetation area index (VAI), i.e., living and dead LAI plus stem area index (SAI). To estimate green graminoid LAI and green dicot LAI, we multiplied the VAI by the fraction of the vegetation area composed of green graminoid and green dicot leaves, respectively. To do this we estimated the fraction of green graminoid leaf, green dicot leaf, and nonphotosynthetic leaves and stems in the groundlayer at 80 points at $1-\mathrm{m}$ intervals along four $20-\mathrm{m}$ transects in each site at each sampling date. At each point, a 1-m thin metal rod painted with white rings at $1.0-\mathrm{cm}$ intervals was inserted vertically into the groundlayer vegetation. All contacts between the vegetation and any of the white rings were tabulated as green graminoid leaf, green dicot leaf, or nonphotosynthetic material. The sum of these counts for the 80 points was used to estimate the fractional composition of these three components. Measurements were performed nine times between September 2002 and October 2003.
We compared data obtained with this approach with destructive harvests of groundlayer vegetation. Grass and dicot green LAI was estimated as described above within $140.5-\mathrm{m} \times 0.5-\mathrm{m}$ plots located to represent a range of LAI values. VAI was estimated in each plot with five replicated measurements with the LAI-2000, and the fraction of graminoid leaf, dicot leaf, and nonphotosynthetic area was determined with the graduated rod at 20 points within the plot. All groundlayer vegetation was harvested from the plot, and the area of dicot and grass leaves was determined with a CI-202 area meter (CID, Inc., Vancouver, WA, EUA).

\section{Tree and shrub LAI}

The LAI-2000 tends to underestimate LAI, when vegetation is strongly aggregated (LI-COR 1992), posing a problem for estimating tree LAI in savanna. To avoid this problem, we made measurements only under tree canopies at points where the entire angle of view intercepted one or more tree or shrub crowns. Since these measurements yield the leaf area per unit crown area, we refer to this as crown LAI. Subsequently, to obtain an estimate of overall LAI, the crown LAI value was multiplied by the fraction of ground area covered by tree and/or shrub crowns (Asner et al. 1998).

In each physiognomy, we permanently marked 50 locations that permitted measurements including only tree or shrub crowns. Measurements at these locations were performed with a $45^{\circ}$ view cap and only during periods of diffuse sunlight, such as on cloudy days or at dusk or dawn. Measurements were performed within a few days of each of the nine sampling dates for the groundlayer LAI, with an additional set of measurements performed in November 2003.

To validate this approach to estimating LAI, we compared estimates performed with the LAI2000 and subsequent destructive measurements of LAI for 14 trees and shrubs. Crown area was estimated from measurements of the major and minor axis by assuming the crown to be an ellipse. Five measurements of LAI were performed for every individual with the LAI 2000. All leaves were collected from the tree, and stem area index (SAI) of the defoliated tree was estimated with the LAI2000 using the same procedure. The area of a subsample of approximately 30 leaves was measured with a CI-202 area meter. The subsample and the remaining leaves were dried to constant mass at $70^{\circ} \mathrm{C}$ and total leaf area determined using the ratio of leaf area to leaf mass determined from the subsample. Total leaf area was converted to crown LAI by dividing by the crown area.

We use repeated-measures ANOVA to test for differences in seasonality of leaf display among plant types (trees, groundlayer dicots, and groundlayer graminoids). We used vegetation type as the blocking factor (von Ende 1993), with month and plant type as fixed factors. Mean squares were calculated with JMP 5.1 and the appropriate $F$ values were calculated manually accord- 
ing to Steel and Torrie (1980). All LAI values were $\log _{10}$ transformed prior to analysis to ensure that comparisons of seasonality were based on relative changes in LAI rather than absolute changes.

\section{Soil water potential}

Soil psychrometers (Wescor PST-55-30 SF) were installed at depths of $10,20,30,60$, and $100 \mathrm{~cm}$ at four locations in each of the five intensively studied sites. Water potential was recorded with a Campbell CR7 data logger that was rotated among the five sites at approximately weekly intervals from June to November 2002, and was kept continuously at the cerrado denso site from April to August 2003. To relate soil water potential to LAI, we used published rooting distributions for tropical savanna (Jackson et al. 1997) to obtain a depth-weighted mean water potential for each date.

Comparisons between savanna and forest species

In November 2003 (wet season), we compared the LAI of congeneric savanna and forest trees under similar growing conditions. We made measurements only on genera containing both a savanna and a forest species to ensure phylogenetic independence, an important condition for inference in comparative studies (Felsenstein 1985), and to improve the statistical power of comparisons between the two groups (Ackerly 1999). One exception is that we included two species from two genera of the family Myrtaceae (Table 1). However, since no other genus from this family was included in the study, phylogenetic independence is maintained.

To control for site differences, we only measured individuals that had established within the savanna environments at either the IBGE reserve or at a nearby site of native cerrado vegetation. In the case of forest species, this was possible because long-term fire protection at IBGE has permitted forest species to establish in savanna. For $H$. martiana, we used individuals planted in cerrado soils at least 20 years previously, with no management for at least the past 15 years and perhaps longer, allowing savanna grasses to recolonize the site.

Using the methods described above for measuring crown LAI, we only measured LAI of individuals in savanna sites where unobstructed measurements of LAI of a single species was possible. Two to 15 individuals $($ mean $=9.2)$ were measured per species. All four species with fewer than seven measured individuals were forest species for which we were unable to locate additional individuals that had established in savanna. We used the $t$ test to compare LAI of the savanna and the forest species within each genus. Additionally, to test for a difference between savanna and forest species across all genera, we performed a paired $t$ test on species means, with pairings being based on genera.

In November 2003, we also measured LAI of gallery forests along three different streams, locally known as the Pitoco, Taquara, and Monjolo forests. LAI was measured at 25 points in each forest, located at $5-\mathrm{m}$ intervals along five transects placed perpendicular to the forest edge.

\section{Remote sensing}

We compared our ground-based estimates of LAI with two vegetation indices derived from Moderate Resolution Imaging Spectroradiometer (MODIS) images (http://modis.gsfc.nasa.gov/). We used 16-day composites of the MODIS enhanced vegetation index (EVI) and the MODIS normalized difference vegetation index (NDVI) products (Huete et al. 2002) at 500-m resolution. The densest site (cerradão) was excluded because the extent of this vegetation type at the study site was
Table 1 Congeneric species pairs studied

\begin{tabular}{lll}
\hline Savanna species & Forest species & Family \\
\hline Aegiphilia lhotzkiana Cham. & A. sellowiana Cham. & Verbenaceae \\
Aspidosperma tomentosum Mart. & A. subicanum Mart. & Apocynaceae \\
Byrsonima crassa Nied. & B. laxiflora Griseb & Malpighiaceae \\
Erythroxylum suberosum St. Hil. & E. daphnites Mart. & Erythroxylaceae \\
Guapira noxia (Netto) Lundell & G. areolata (Heimerl) Lundell & Nyctaginaceae \\
Hymenaea stignocarpa Mart. & H. martiana Hayne & Leguminosae - Caes. \\
Ex Hayne & M. acuminata (Steud.) Naudin & Melastomataceae \\
Miconia pohliana Cogn. & O. castaneaefolia (St. Hil.) Engl. & Ochnaceae \\
Ouratea hexasperma (St. Hil.) Bail. & Myrcia rostrata DC. & Myrtaceae \\
Blepharocalyx salicifolius & M. ferruginea & Myrsinaceae \\
(H.B.K.) Berg. & (Ruiz and Pav.) Spreng. & Sapotaceae \\
Myrsine guianensis (Aubl.) & Pouteria sp. & Symplocaceae \\
O. Kuntz & S. mosenii Brand. & Vochysiaceae \\
Pouteria ramiflora (Mart.) Radlk. & V. tucanorum (Spreng.) Mart & \\
A. DClocos lanceolata (Mart.) & & \\
Vochysia thyrsoidea Pohl. & &
\end{tabular}


much smaller than the resolution of the MODIS data products.

\section{Results}

The relationship between destructively measured LAI and values measured with the LAI 2000 did not vary significantly from a 1:1 line for the groundlayer (Fig. 1a, $\left.t_{27}=1.66, P=0.11\right)$. However, the LAI2000 significantly underestimated tree and shrub LAI (Fig. $1 \mathrm{~b}, t_{14}=2.69$, $P=0.018$ ), so the raw data from other measurements on trees and shrubs were multiplied by a scaling constant of 1.174 , as determined from the regression relationship shown in Fig. $1 b$.

For the destructively harvested individuals, stem area index (SAI) estimated with the LAI2000 was

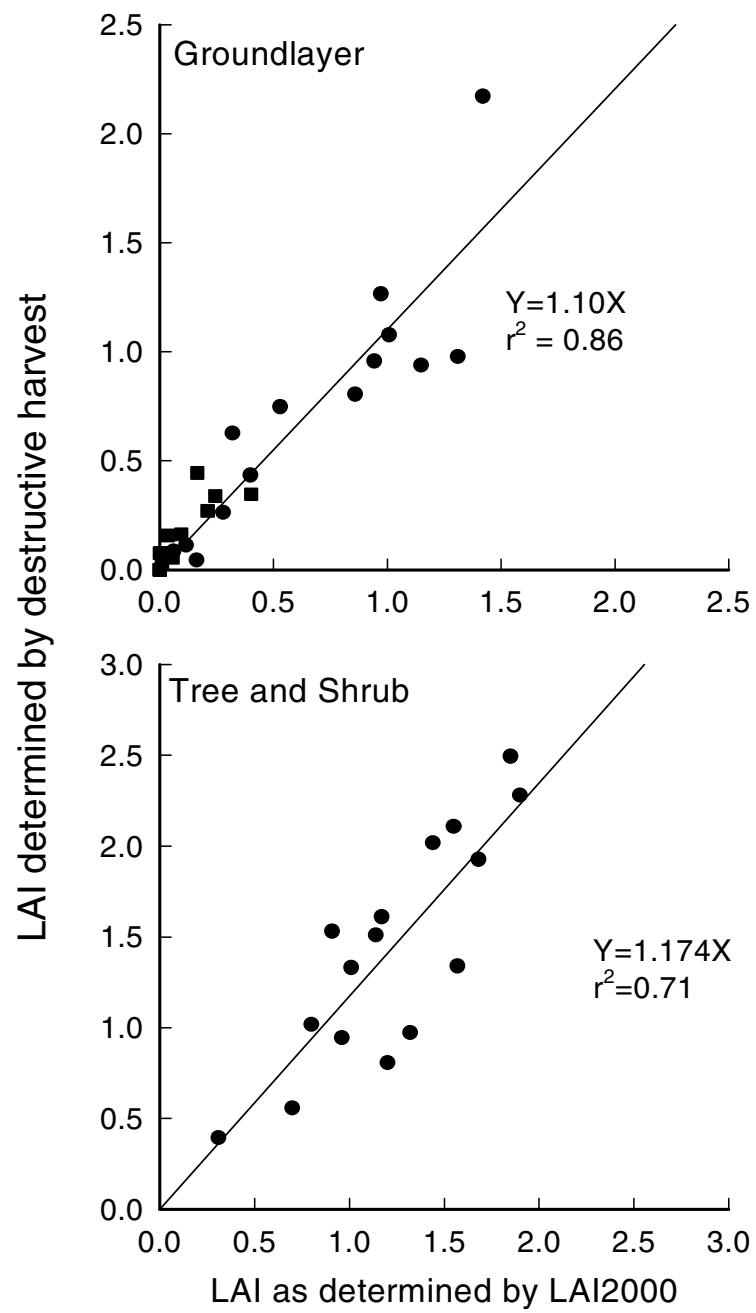

Fig. 1 Relationship between LAI measurements made with the LAI-2000 and those determined by destructive harvests. a Groundlayer LAI. Circles represent graminoids and squares represent dicots. The relationship did not deviate significantly from a 1:1 line. b LAI of woody plants over 1-m tall. Measurements with the LAI-2000 significantly underestimated woody plant LAI $(P=0.02)$
$13.9 \pm 1.6 \%$ (mean $\pm \mathrm{SE}$ ) of the total vegetation area index. This represents the percentage of vegetation area index attributable to stems at the time of maximum leaf display during the wet season. To estimate the contribution of stems to total VAI, we assumed that this same percentage is representative of all sites during the wet season, and that SAI does not vary seasonally.

$$
\begin{aligned}
& \multimap-\text { Campo Sujo } \\
& -\Delta-\text { Campo Cerrado } \\
& -\square-\text { Cerrado Sensu Stricto } \\
& -\checkmark-\text { Cerrado Denso } \\
& \ldots . . . \text {... Cerradão }
\end{aligned}
$$
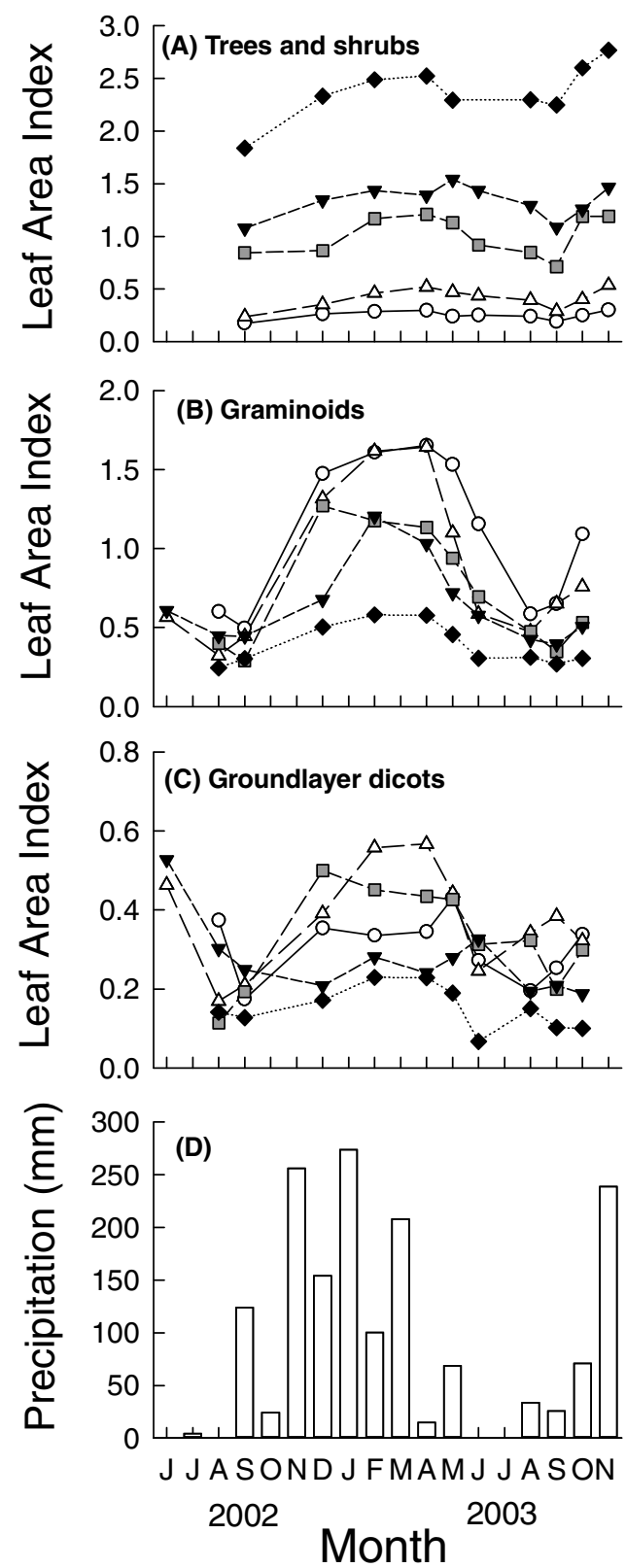

Fig. 2 Seasonality of LAI and precipitation at the study site. a Green LAI of woody plants taller than $1 \mathrm{~m}$. b Green LAI of graminoids. c Green LAI of groundlayer dicots. d Monthly precipitation 
The three plant types (graminoids, groundlayer dicots, and trees) differed significantly in their seasonality of LAI (Fig. 2; type $\times$ time interaction $\left.F_{2,64}=6.87, P \ll 0.001\right)$. Grasses exhibited much greater seasonality than did woody plants (Fig. 2a, b). For trees and shrubs, late dry season LAI (September) averaged $68 \%$ of wet season values (February and April), whereas for grasses, late dry season LAI was $28 \%$ of wet season values (Fig. 2b). Seasonality of groundlayer dicots was intermediate, with late dry season LAI being $60 \%$ of that of the wet season (Fig. 2c). As a result, most of the seasonality in groundlayer LAI can be attributed to graminoids rather than dicots. During periods of soil drying, grass LAI was strongly correlated to soil water potential (Fig. 3, $r^{2}=0.59, P=0.002$ ), while tree LAI was less strongly correlated (Fig. 3, $r^{2}=0.30, P=0.05$ ), and LAI of groundlayer dicots was uncorrelated to soil water potential $\left(r^{2}=0.03, P=0.57\right)$. There was considerable hysteresis in the relationship between LAI and soil water potential; during the wetting phase at the beginning of the wet season, there was no relationship between soil water potential and LAI (Fig. 3). During this period, soil water potential in the top $1 \mathrm{~m}$ very quicky approached $0 \mathrm{MPa}$, while LAI attained maximum values only after several months.

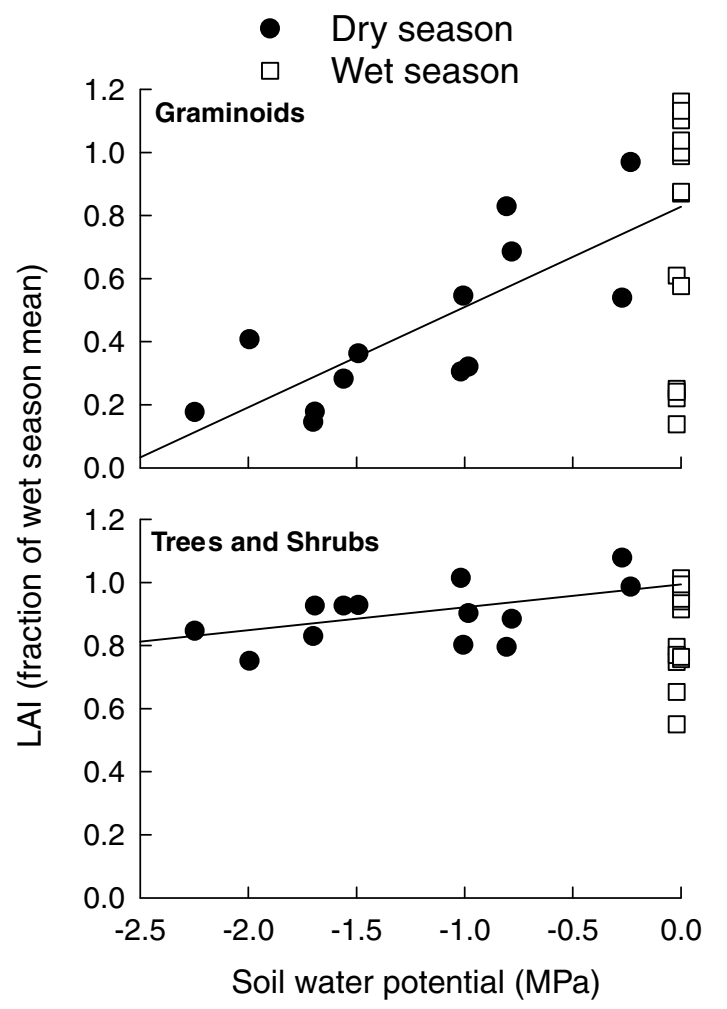

Fig. 3 Relationship between soil water potential and LAI. During the dry season, there was a significant relationship between soil water potential and LAI of graminoids (top, $r^{2}=0.59, P=0.002$ ) and woody plants (bottom, $r^{2}=0.30, P=0.05$ )
Wet-season tree and shrub LAI varied greatly among sites (Fig. 4), primarily due to a sixfold difference in percentage crown cover, which varied from $16 \%$ to $91 \%$ (Fig. 4a). In contrast, mean wet season crown LAI (i.e. LAI of individual trees and clusters) ranged from 1.37 to 2.59 among sites, less than a twofold difference (Fig. 4b). The net result of these differences is a ninefold difference in ecosystem-level tree and shrub LAI among sites, ranging from 0.28 at the campo sujo site to 2.48 at the cerradão site (Fig. 4c). Wet season LAI of the three gallery forest sites ranged from 3.87 to 4.55 $($ mean $=4.15)$.

Total groundlayer green LAI (grass LAI + dicot LAI) was strongly and negatively correlated with tree cover among sites (Fig. 5). Similarly, grass LAI was negatively correlated with tree cover, though
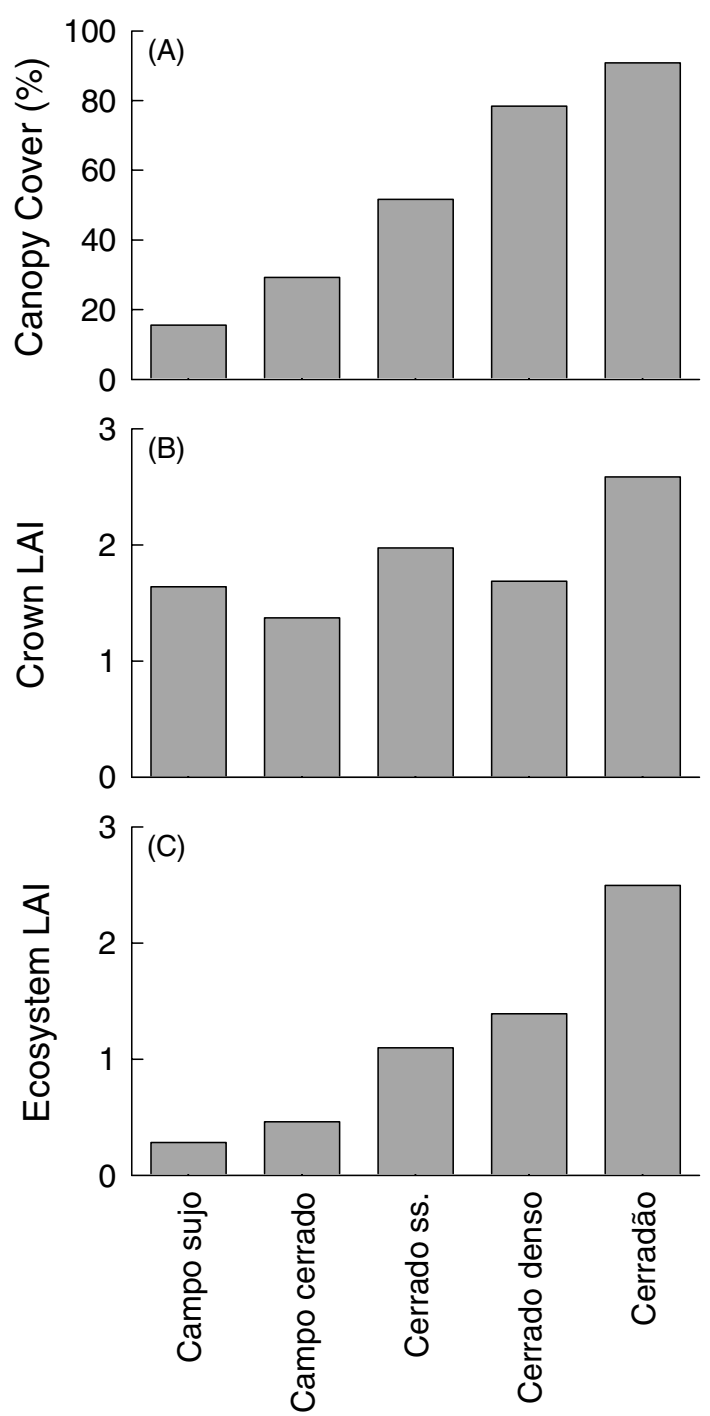

Fig. 4 Components of the among-site variation in wet season tree and shrub LAI. a Percentage of ground area covered with tree or shrub crowns, b mean LAI of the crowns of individuals and clumps of individuals, c overall LAI as obtained by multiplying fractional canopy cover and crown LAI to obtain total tree and shrub LAI 

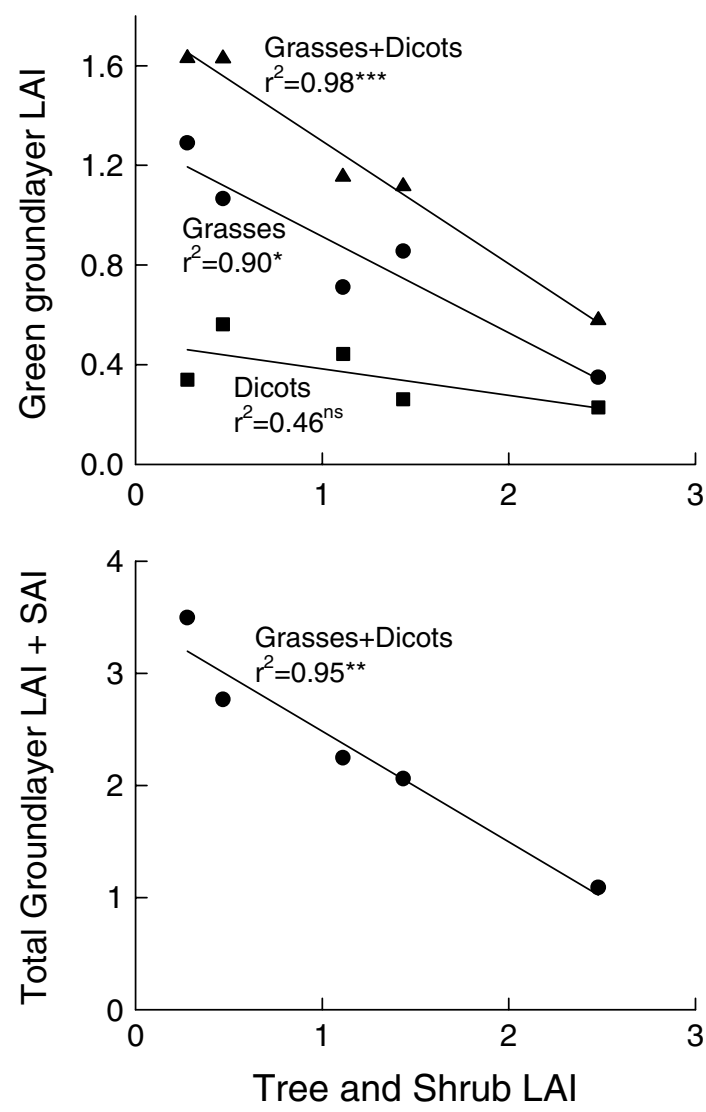

Fig. 5 a Relationship between wet-season woody plant LAI and green groundlayer LAI across the five study sites. The regression equations are $y_{\text {total }}=1.79-0.49 x, \quad y_{\text {grass }}=1.30-0.39 x$ and $y_{\text {dicot }}=0.49-0.11 x$. b Relationship between wet-season woody plant LAI and total groundlayer LAI and stem area index $(S A I)$. These values include all living and dead components of the groundlayer vegetation, including dicots and graminoids. The regression equation is $y=2.47-0.95 x$. All values are averages from February and April 2003, the months with peak LAI

that of groundlayer dicots was not (Fig. 5). Total VAI (living and dead LAI plus SAI) of the ground layer was also negatively correlated with tree LAI (Fig. 5).

Sites with less tree cover tended to have a greater relative decline in total LAI during the dry seasons $\left(r^{2}=0.92, \quad P=0.01\right)$. This was due primarily to the greater contribution of the more seasonal grasses to overall LAI in open sites $\left(r^{2}=0.92, P=0.01\right)$. There were trends towards reduced seasonality of LAI with increasing tree density for trees $\left(r^{2}=0.75, P=0.056\right)$ and the groundlayer $\left(r^{2}=0.48, P=0.19\right)$. Though not statistically significant, these trends nevertheless contributed somewhat to the lower overall seasonality of LAI in denser sites.

In $6 / 12$ genera, the savanna species had significantly lower crown LAI than forest species under similar growing conditions (Fig. 6). When compared over all genera, LAI was $46 \%$ greater for forest species (paired $t_{11 d f}=3.37 ; P=0.006$ ). Mean LAI of forest species was

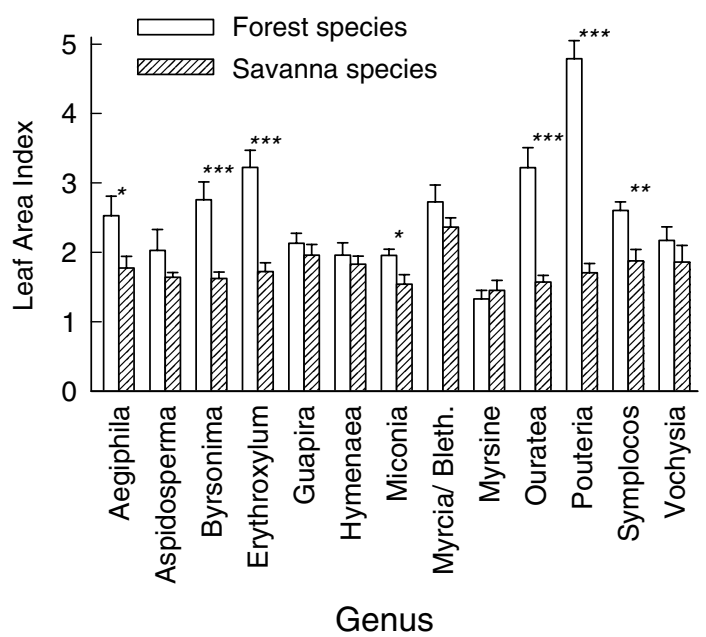

Fig. 6 Mean $(+$ SE) LAI of congeneric savanna and forest species growing in open savanna environments. ${ }^{*} P<0.05$, $* * 0.01<P<0.05, * * * 0.005<P<0.01$ for comparisons between savanna and forest species within a genus. Overall forest species had $46 \%$ greater LAI than savanna species $(P=0.006)$

$2.57 \pm 0.24$, while mean LAI of savanna species was $1.76 \pm 0.06$ (mean $\pm \mathrm{SE}$ ).

Both EVI and NDVI were positively correlated to LAI, but the relationship was stronger for EVI (Fig. 7).

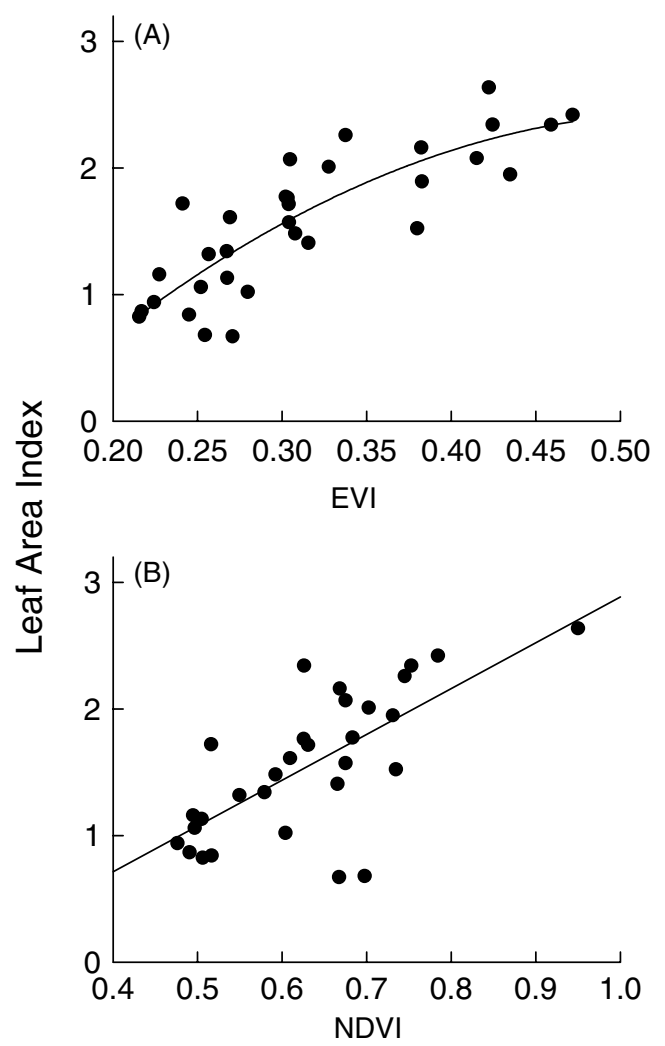

Fig. 7 Relationship between LAI and MODIS vegetation index products. Each point represents one site at one measurement date. a Enhanced vegetation index $(E V I)$. LAI $=-15.08 \mathrm{EVI}^{2}+$ 16.33EVI $-1.98, r^{2}=0.71$. b Normalized difference vegetation index $(N D V I)$ LAI $=3.62 \mathrm{NDVI}-0.73, r^{2}=0.49$ 


\section{Discussion}

Tree cover clearly exerts a strong influence on grasses in these savannas. The negative relationship between tree LAI and grass LAI indicates that the negative effects of trees on grasses substantially outweigh any positive effects over the range of tree densities examined here. Although tree cover was shown to stimulate grass production in some savannas (Belsky et al. 1989; Weltzin and Coughenour 1990; Belsky 1994; Mordelet and Menaut 1995), tree cover usually reduces grass production in savannas receiving $>800 \mathrm{~mm} \mathrm{year}^{-1}$ of precipitation (Mordelet and Menaut 1995). The mean precipitation at the study site is over $1,400 \mathrm{~mm}$ year $^{-1}$, so a negative effect on the ground layer is expected.

Extrapolating the relationship between tree LAI and grass LAI indicates that savanna grasses should not tolerate environments where tree LAI exceeds 3.3. In the gallery forest sites, where mean wet season tree LAI was 4.15, well over the value that should exclude grasses, savanna grasses are indeed absent. The higher LAI in gallery forest may partly result from greater water or nutrient availability, but species composition also plays an important role. Overall, forest species had $46 \%$ greater LAI than congeneric savanna species growing under similar conditions. This has important implications for fire occurrence and the dynamics of savannaforest boundaries, since grasses are the primary fuel in tropical savannas, with groundlayer VAI being strongly correlated to fine fuel mass (Hoffmann et al. 2004a). The lack of grasses and the more humid understory afforded by the closed canopy greatly reduce the risk that savanna fires penetrate far into forest (Kellman and Meave 1997; Biddulph and Kellman 1998). Evergreen forest trees are more sensitive to fire than savanna species (Hoffmann and Moreira 2002), largely due to thinner bark (Hoffmann et al. 2003) and smaller below-ground reserves of nonstructural carbohydrates (Hoffmann et al. 2004b), so exclusion of grasses is essential for persistence of remaining evergreen forest within savanna landscapes.

The higher LAI of forest species appears to play an important role in cerradão, where forest and savanna species coexist. The presence of forest species should permit stands to attain higher values of LAI than in more open forms of cerrado. In fact, crown LAI was highest in cerradão (Fig 4b), largely due to the presence of forest species with dense foliage such as Ocotea pomaderroides and Emmotum nitens (W. Hoffmann, personal observation). Although species composition of the tree layer may contribute to the higher LAI of cerradão and gallery forest, it did not seem to play an important role in determining the differences in LAI among the four most open sites. Although tree species composition tends to change over the gradient in tree density represented by these four sites (Moreira 2000; Ribeiro and Tabarelli 2002), this appears not to contribute to the differences in LAI, since crown LAI varied little among these sites.
We expected savanna trees to exhibit lower crown LAI than forest species based on findings that shadetolerant species often have higher LAI than shadeintolerant species (Mourelle et al. 2001; Sterck et al. 2001; Reich et al. 2003). Shade tolerance should permit species to develop greater LAI because their leaves can maintain a positive carbon balance under greater self-shading due to a lower light compensation point for photosynthesis. Fully expanded leaves are unable to upload carbohydrates from the phloem (Turgeon 1989), so a leaf will eventually senesce if it receives insufficient light to maintain a positive carbon balance. While the degree of shade tolerance should restrict the maximum LAI that a species can develop, it would not constrain the minimum LAI of a species. Because of this, along with the fact that many forest species are shade intolerant, we should not expect that all genera would show a significant difference in LAI between savanna and forest species. In fact, for half of the genera there was no difference in mean LAI between savanna and forest species.

Across sites, wet season green LAI of the groundlayer declined by approximately 0.5 units for every 1.0 unit increase in woody plant LAI (Fig. 4). Since the decline in groundlayer LAI does not entirely offset the increase in tree LAI, total LAI in the wet season is highest in sites with the greatest tree cover. The role of tree cover in determining spatial variation in total LAI becomes even more important in the dry season, when groundlayer LAI is greatly diminished. We expect similar patterns in transpiration and primary productivity, whereby sites with greater tree density should exhibit greater maximum fluxes, as well as greater seasonality.

Grass LAI tracked soil water potential during the dry season, but these became quickly uncoupled after the onset of rains when LAI lagged behind soil water potential. Soil water potential has been successfully used as the primary determinant for modeling leaf phenology in tropical savannas (Jolly and Running 2004), but it is not clear whether soil water potential is an important cue for phenology of trees. Leaf fall of savanna trees often occurs before the beginning of the dry season (Simioni et al. 2004), while leaf flush commonly occurs before the first rains at the end of the dry season (Gouveia 1998; Prior et al. 2004; Simioni et al. 2004). To discern what environmental cues are drivers of tree phenology, long-term monitoring of inter-annual variations will be necessary. NDVI has been frequently used to monitor phenology of tropical savannas (Fuller and Prince 1996; Jolly and Running 2004), but here EVI was more strongly correlated to LAI. This suggests that EVI is a more appropriate vegetation index for this purpose, corroborating the results of Ferreira et al. (2003). Although EVI is useful for monitoring leaf phenology at the ecosystem level, it does not distinguish between tree and grass LAI and therefore does not capture the complexity of tree-grass interactions in tropical savanna. 
Acknowledgements We thank Augusto C. Franco for comments on the manuscript and Mercedes Bustamante for use of the LAI2000 Plant Canopy Analyzer. This work was supported by a grant from the National Science Foundation (USA) grant\# 0296174. This work complies with Brazilian law.

\section{References}

Ackerly DD (1999) Comparative plant ecology and the role of phylogenetic information. In: Press MC, Scholes JD, Barker MG (eds) Physiological Plant Ecology. Blackwell Science, Oxford, pp 391-412

Asner GP, Wessman CA, Archer S (1998) Scale dependence of absorption of photosynthetically active radiation in terrestrial ecosystems. Ecol Appl 8:1003-1021

Asner GP, Scurlock JMO, Hicke JA (2003) Global synthesis of leaf area index observations: implications for ecological and remote sensing studies. Glob Ecol Biogeogr 12:191-205

Belsky AJ (1994) Influences of trees on savanna productivity: tests of shade, nutrients, and tree-grass competition. Ecology 75:922-932

Belsky AJ, Amundson RG, Duxbury JM, Riha SJ, Ali AR, Mwong SM (1989) The effects of trees on their physical, chemical, and biological environments in a semi-arid savanna in Kenya. $\mathbf{J}$ Appl Ecol 26:1005-1024

Biddulph J, Kellman M (1998) Fuels and fire at savanna gallery forest boundaries in southeastern Venezuela. J Trop Ecol $14: 445-461$

Bonan GB (2002) Ecological climatology. Cambridge University Press, Cambridge

Bowman DMJS (2000) Australian rainforests: islands of green in a land of fire. Cambridge University Press, Cambridge

von Ende CN (1993) Repeated-measures analysis: growth and other time-dependent measures. In: Scheiner SM, Gurevitch J (eds) Design and analysis of ecological experiments. Chapman and Hall, New York, pp 113-137

Felsenstein J (1985) Phylogenies and the comparative method. Am Nat 125:1-15

Ferreira LG, Yoshioka H, Huete A, Sano EE (2003) Seasonal landscape and spectral vegetation index dynamics in the Brazilian Cerrado: an analysis within the large-scale biosphereatmosphere experiment in Amazonia (LBA). Remote Sens Environ 87:534-555

Fölster H, Dezzeo N, Priess JA (2001) Soil-vegetation relationship in base-deficient premontane moist forest-savanna mosaics of the Venezuelan Guayana. Geoderma 104:95-113

Fuller DO, Prince SD (1996) Rainfall and foliar dynamics in tropical sounther Africa: potential impacts of global climate change on savanna vegetation. Clim Change 33:69-96

Furley PA (1992) Edaphic changes at the forest-savanna boundary with particular reference to the neotropics. In: Furley PA, Proctor J, Ratter JA (eds) Nature and dynamics of forest-savanna boundaries. Chapman and Hall, London, pp 91-117

Goodland R, Ferri MG (1979) Ecologia do Cerrado. Livraria Itatiaia Editora LTDA, Belo Horizante

Gouveia GP (1998) Phenology of cerrado and gallery forest communities in central Brazil. Revista Árvore 22:443-450

Haridasan M (1992) Observations on soils, foliar nutrient concentrations and floristic composition of cerrado sensu stricto and cerradão communities in central Brazil. In: Furley PA, Proctor J, Ratter JA (eds) Nature and dynamics of forest-savanna boundaries. Chapman and Hall, London, pp 171-184

Hibbard KA, Archer S, Schimel DS, Valentine DW (2001) Biogeochemical changes accompanying woody plant encroachment in a subtropical savanna. Ecology 82:1999-2011

Hoffmann WA et al (2004a) Impact of the invasive grass Melinis minutiflora at the savanna-forest ecotone in the Brazilian Cerrado. Divers Distrib 10:99-103

Hoffmann WA, Moreira AG (2002) The role of fire in population dynamics of woody plants. In: Oliveira PS, Marquis RJ (eds)
The Cerrados of Brazil: ecology and natural history of a neotropical savanna. Columbia University Press, New York

Hoffmann WA, Orthen B, Nascimento PKV (2003) Comparative fire ecology of tropical savanna and forest trees. Funct Ecol $17: 720-726$

Hoffmann WA, Orthen B, Franco AC (2004b) Constraints to seedling success of savanna and forest trees across the savannaforest boundary. Oecologia 140:252-260

Huete A, Didan K, Miura T, Rodriguez EP, Gao X, Ferreira LG (2002) Overview of the radiometric and biophysical performance of the MODIS vegetation indices. Remote Sens Environ 83:195-213

Isichei AO, Muoghalu JI (1992) The effects of tree canopu cover on soil fertility in a Nigerian savanna. J Trop Ecol 8:329-338

Jackson RB, Mooney HA, Schulze E-D (1997) A global budget for fine root biomass, surface area, and nutrient contents. Proc Nat Acad Sci 94:7362-7366

Jolly WM, Running SW (2004) Effects of precipitation and soil water potential on drought deciduous phenology in the Kalahari. Glob Change Biol 10:303-308

Kellman M (1979) Soil enrichment by neotropical forest trees. J Ecol 67:565-577

Kellman M, Meave J (1997) Fire in the tropical gallery forests of Belize. J Biogeogr 24:23-34

Le Roux X, Bariac T, Mariotti A (1995) Spatial partitioning of the soil water resource between grass and shrub components in a West African humid savanna. Oecologia 104:147-155

LI-COR (1992) LAI-2000 Plant canopy analyzer. LI-COR Inc., Lincoln, NE, USA

Ludwig F, Dawson TE, de Kroon H, Berendse F, Prins HHT (2003) Hydraulic lift in Acacia tortilis trees on an East African savanna. Oecologia 134:293-300

Ludwig F, Dawson TE, Prins HHT, Berendse F, de Kroon H (2004) Below-ground competition between trees and grasses may overwhelm the facilitative effects of hydraulic lift. Ecol Lett 7:623-631

Mordelet P, Menaut J-C (1995) Influences of trees on aboveground production dynamics of grasses in a humid savanna. $\mathrm{J}$ Veg Sci 6:223-228

Mordelet P, Abbadie L, Menaut JC (1993) Effects of tree clumps on soil characteristics in a humid savanna of West Africa. Plant Soil 153:103-111

Moreira AG (2000) Effects of fire protection on savanna structure in Central Brazil. J Biogeogr 27:1021-1029

Moreira M et al. (2003) Hydraulic lift in a neotropical savanna. Funct Ecol 17:573-581

Moreira AG, Klink CA (2000) Biomass allocation and growth of tree seedlings from two contrasting Brazilian savannas. Ecotropicos 13

Mourelle C, Kellman M, Kwon L (2001) Light occlusion at forest edges: an analysis of tree architectural characteristics. For Ecol Manage 154:179-192

Prior LD, Eamus D, Bowman DMJS (2004) Tree growth rates in north Australian savanna habitats: seasonal patterns and correlations with leaf attributes. Aust J Bot 52:303-314

Reich PB et al. (2003) The evolution of plant functional variation: traits, spectra, and strategies. Int J Plant Sci 164:S143S164

Ribeiro LF, Tabarelli M (2002) A structural gradient in cerrado vegetation of Brazil: changes in woody plant density, species richness, life history and plant composition. J Trop Ecol 18:775-794

Rizzini CT, Heringer EP (1961) Underground organs of plants from some southern Brazilian savannas with special reference to the xylopodium. Phyton 17:105-124

Scholes RJ, Archer S (1997) Tree-grass interactions in savannas. Annu rev Ecol Syst 28:517-544

Scholz FG, Bucci SJ, Goldstein G, Meinzer FC, Franco AC (2002) Hydraulic redistribution of soil water by neotropical savanna trees. Tree Physiol 22:603-612

Schwartz D, Floresta H, Mariotti A, Balesdent J, Massimba JP, Girardin C (1996) Present dynamics of the savanna-forest 
boundary in the Congolese Mayombe: a pedological, botanical and isotopic $\left({ }^{13} \mathrm{C}\right.$ and $\left.{ }^{14} \mathrm{C}\right)$ study. Oecologia 106:516-524

Simioni G, Gignoux J, Le Roux X, Appé R, Benest D (2004) Spatial and temporal variations in leaf area index, specific leaf area and leaf nitrogen of two co-occurring savanna tree species. Tree Physiol 24:205-216

Steel RGD, Torrie JH (1980) Principles and procedures of statistics, 2nd edn. McGraw-Hill, New York

Sterck FJ, Bongers F, Newbery DM (2001) Tree architecture in a Bornean lowland rain forest: intraspecific and interspecific patterns. Plant Ecol 153:279-292
Turgeon R (1989) The sink-source transition in leaves. Annu Rev Plant Physiol Plant Mol Biol 40:119-138

Uhl C, Kauffman JB (1990) Deforestation, fire susceptibility and potential tree responses to fire in the eastern Amazon. Ecology $71: 437-449$

Weltzin JF, Coughenour MB (1990) Savanna tree influence on understory vegetation and soil nutrients in northwestern Kenya. J Veg Sci 1:325-334 